\title{
Adoption of Improved Technologies in Maize-Based Cropping Systems on Income of Farmers in Ondo State, Nigeria
}

\author{
Owoeye R. S. \\ Department of Agricultural Economics and Extension Services, Ekiti State University, Ado - Ekiti, Nigeria
}

Email address:

doneta113@yahoo.com, ufus.owoeye@eksu.edu.ng

To cite this article:

Owoeye R. S. Adoption of Improved Technologies in Maize-Based Cropping Systems on Income of Farmers in Ondo State, Nigeria. American Journal of Theoretical and Applied Business. Vol. 3, No. 2, 2017, pp. 18-22. doi: 10.11648/j.ajtab.20170302.11

Received: March 24, 2017; Accepted: April 25, 2017; Published: June 5, 2017

\begin{abstract}
This study examined the adoption of improved technologies in maize-based farming systems on income of farmers in Ondo state, Nigeria. It specifically identifies the socio-economic characteristics, determines the intensity of adoption of improved technologies introduced to maize-based farmers and examine the effect of adoption of improved technologies on their income in the study area. Multi-stage sampling technique was used to obtain data from 160 maize-based farmers that were selected from 3 Local Government Areas in Ondo State. Descriptive Statistical Analysis, Budgetary Technique Analysis and Tobit Regression Analysis were used to analyze the data. Results on socio-economic characteristics disclosed that most (59.82 percent) of the respondents were relatively old (more than 50 years) with the mean age of 54.76 years. Also, 50.63 percent of the respondents had between 5 and 8 members in their households. It was revealed that only 29.62 percent of the respondents had secondary education and above. The farmers were well experienced with 65 percent of them having more than 20 years of farming experience and 73.75 percent of them had less than 2 hectares of land as farm size. The result of profitability analysis shows that the total revenue, gross margin and net farm income for the improved technology adopters are $\$ 750,450, \$ 573,130$ and $\$ 521,940$ respectively. On the other hand, the total revenue, gross margin and net farm income for the non-adopters of improved technology are $\$ 320,140, \$ 244,180$ and $\$ 227,830$ respectively, implying that improved technology adopters performed way better than non-adopters in terms of total revenue, gross margin and total cost. The determinants of intensity of adoption of improved technologies in the study area as shown by Tobit regression estimate revealed that age, extension access, farming experience, marital status, household size, farm size and educational level were statistically significant, implying that they are the important variables found to greatly influence the intensity of adoption of improved technologies by maize-based farmers in Ondo state. It is therefore recommended that policy option requires the traditional technology users to embrace the improved agricultural technologies in order to increase their earning per unit of land cultivated should be introduced.
\end{abstract}

Keywords: Adoption, Improved Technology, Maize, Budgetary Technique and Tobit Regression Analysis

\section{Introduction}

Agriculture which is the main stay of the Nigerian economy, involves small scale farmers scattered over wide expanse of land area, with small holding ranging from 0.5 to 3.0 hectare per farm land. It is characterized by rudimentary farm systems, low capitalization and low yield per hectare [7]. It contributes immensely to the economy of Nigeria in various ways, namely, in the provision of food for the increasing population; supply of adequate raw materials (and labour input) to a growing industrial sector; a major source of employment; generation of foreign exchange earnings; and, provision of a market for the products of the industrial sector [6].

Nigeria is an agrarian country with about $70 \%$ of her over 140 million people engaged in agricultural production [10] and provides subsistence for two-thirds of Nigerians who are low income earners [12]. While the Northern part can guarantee the production of cereals such as sorghum, maize, millet, groundnut, cowpea and cotton, the Middle Belt and 
the Southern part have the potentials to produce root tubers such as cassava, yam, cocoyam and other crops like plantain as well as maize [1]. In addition to crops, Nigeria is also involved in the production of livestock, fisheries, forestry and wildlife.

The roles of agriculture remain significant in the Nigerian economy despite the strategic importance of the oil sector. Agriculture provides primary means of employment for Nigeria and accounts for more than one third of total Gross Domestic Product (GDP) and labour force. The rate of growth of Nigeria's food production is $2.5 \%$ per annum in recent years, while food demand has been growing at the rate of more than $3.5 \%$ per annum due to high rate of population growth of $2.83 \%$ [7]. Some of major problems militating crop production in Nigeria are climatic factors (rainfall, temperature and solar radiation), soil factors, migration, socioeconomic considerations and government policies, pests and diseases among others. However, the ability of Nigerian agriculture to perform its role in development has been on the decline in recent years. The overall agricultural situation deteriorated creating a wide gap in the supply and demand for food [4].

Maize (Zea mays L), also referred to as corn in some parts of the world is a crop grown wildly in a range of agroecological environments. It is the most important cereal crop in Sub-Saharan Africa (SSA) and an important staple food for more than 1.2 billion people in SSA and Latin America. All parts of the crop can be used for food and non-food products. It is a major cereal being cultivated in the rainforest and derived savannah zones of Nigeria. It is the third most important cereal crop after wheat and rice, providing food for humans and animals and serving as a basic raw material for the production of starch, alcoholic beverages, food sweeteners and fuel [4].

The importance of maize cannot be overemphasized, with Nigeria producing $43 \%$ of maize grown in West Africa [8]. Maize is the most important staple food crop in Nigeria, in the provision of food for man, feed for livestock and raw materials for some agro-based industries. Basically, about $80 \%$ is consumed by man and animals while $20 \%$ is utilized in a variety of industrial processes for the production of starch, corn sweetener, ethanol, cereal and alkaline.

[13] reported that maize is hydrolyzed and enzymatically treated to produce syrups, particularly high fructose corn syrup, sweetner and in some cases fermented and distilled to produce grain alcohol which is traditionally the source of bourbon whisky. Sweet corn is a genetic variation that is high in sugars and low in starch that is served like vegetable. Another common food made from maize is corn flakes. Maize is used as meal pap in Africa; corn bread is made from maize. Maize is still an important model organism for genetic and develops mental biology to date [11].

Maize can be boiled or roasted on the cob, the grains can be cooked fresh or dry and the dry grain can be made into popcorn (guguru) and eaten with roasted groundnuts. Maize consists of $71 \%$ starch, $9 \%$ protein and $4 \%$ oil on a dry weight basis. It accounts for about $43 \%$ of calorie intake [9].
It is an important source of carbohydrate, protein, iron, vitamin B, and minerals. Green maize (fresh on the cob) is eaten parched, baked, roasted or boiled; playing an important role in filling the hunger gap after the dry season and serving as a staple diet for 200 million people [3]. Maize has consumption quantity of $53.20 \mathrm{~g} /$ capital/day [4].

\section{Research Methodology}

\subsection{The Study Area}

The study was carried out in Ondo state, Nigeria. Ondo state is located in the southwestern part of Nigeria, and with a population of 3,441,024 (National Population Commission, 2006). It is bounded in the north by Ekiti and Kogi states, in the east by Edo state, in the southeast by Delta state, in the west by Osun and Ogun states and in the south by the Bight of Benin of the Atlantic Ocean [2]. The state lies between longitudes $4^{\circ} 30^{1}$ and $6^{\circ} 00^{1}$ East of the Greenwich Meridian and latitudes $5^{\circ} 45^{1}$ and $8^{\circ} 15^{1}$ North of the equator. The land area is about $14,793,186$ square kilometer with varying physical features like hills, lowland, rivers creeks and lagoons (Federal Office of Statistics, 1996).

\subsection{Data Source and Data Collection}

The study made use of both primary and secondary data. Primary data were collected using well-structured questionnaire administered to maize-based farmers in the study area. Data were collected on socio - economic variables such as age, level of education, farming experience of the farmers, farm size, family size, access to credit, membership of association, as well as input - output data of the farmer. The input/output data included yield of maize (kg), cost of input, income from output, labour input in man days. Secondary data on adoption were obtained from records and publications from institution such as Food and Agricultural Organization (FAO), Federal Bereau of Statistics (FBS) and the state's Agricultural Development Project, journals, relevant textbooks, previous research reports, internet and other relevant bodies within and outside Nigeria.

\subsection{Sampling Technique}

The research made use of multistage sampling technique. The first stage involved the random selection of three Local Government Areas (Akure North, Ifedore and Idanre LGAs) out of the 18 LGAs in Ondo state which are predominant in maize production. In each of these LGAs, three communities were randomly selected, and then, eighteen maize-based farmers (respondents) were also selected randomly from each community, thereby making a total of one hundred and sixty two (162) respondents. Due to incomplete responses, the study made use of 160 fully filled questionnaire.

\subsection{Analytical Technique}

The study made use of quantitative and qualitative techniques to analyze the data generated. 


\subsubsection{Tobit Model}

The intensity of adoption was measured by intensity of cultivation e.g. in terms of number of farmers, total area cultivated or harvested (CIMMYT, 1993). In order to analyze the intensity of adoption, measured by the average proportion of farmland devoted to improved maize production by the respondents, this study adopted the Tobit model which is a hybrid of the discrete and the continuous dependent variable which originated from the work of Tobin (1958). Tobit model have been adopted in a number of studies (Taha, 2007; Awotide et al., 2012)

Following Maddala (1992) the basic Tobit model is specified as follows:

$$
\begin{aligned}
& \qquad \mathrm{Di} * \lambda \mathrm{Xi}+\mu \mathrm{i} \\
& \qquad \mathrm{Di}=0 \text { if } \mathrm{Di} * \leq 0, \mathrm{Di}=\mathrm{Di} * \text { if } \mathrm{Di} *>0 \\
& \mu \sim \mathrm{IN}\left(0, \sigma^{2}\right) \\
& \mathrm{I}=1,2 \ldots \ldots \ldots \ldots \mathrm{m} \\
& \mathrm{D} *=\text { limited dependent variable, it is the intensity of } \\
& \text { adoption defined as the proportion of farm area devoted to } \\
& \text { improved maize production. } \\
& \mathrm{X}_{\mathrm{i}}=\text { the socio-economic/demographic characteristics of the } \\
& \text { respondents which is the same as the explanatory variables } \\
& \text { above. }
\end{aligned}
$$

\subsubsection{Budgetary Technique}

This was used to estimate the cost and returns of maize farmers in the study area.

$$
\begin{array}{r}
\mathrm{GM}=\mathrm{TR}-\mathrm{TVC} \\
\mathrm{NR}=\mathrm{TR}-\mathrm{TC} \\
\mathrm{TC}=\mathrm{TVC}+\mathrm{TFC}
\end{array}
$$

Where:

$\mathrm{GM}=$ Gross margin, $\mathrm{TR}=$ Total Revenue, $\mathrm{TVC}=$ Total Variable cost, $\mathrm{TFC}=$ Total Fixed Cost, $\mathrm{NR}=\mathrm{Net}$ Returns, $\mathrm{TC}=$ Total Cost.

Straight line method of depreciation was used to calculate the depreciation cost of farm tools and equipment.

$$
\text { Annual Depreciation }=\frac{\mathrm{P}-\mathrm{S}}{N}
$$

$\mathrm{N}=$ economic life of the equipment/tool

$\mathrm{P}=$ purchase price

$\mathrm{S}=$ salvage value

Test of difference of mean was used to test for significant difference in the net farm income of the two categories of farmers. The formula goes thus:

$$
\mathrm{t}=\frac{\overline{x_{1}}-\overline{x_{2}}}{\sqrt{\frac{s_{1}^{2}}{n_{1}}+\frac{s_{2}^{2}}{n_{2}}}}
$$

$\overline{X_{1}}=$ Mean net farm income of the improved technology adopters

$\overline{X_{2}}=$ Mean net farm income of the traditional technology adopters
$\mathrm{S}_{1}{ }^{2}=$ Variance of the net farm income of the improved technology adopters

$\mathrm{S}_{2}{ }^{2}=$ Variance of the net farm income of the traditional technology adopters

$\mathrm{n}_{1}=$ Number of improved technology adopters

$\mathrm{n}_{2}=$ Number of traditional technology adopters

\section{Result and Discussion}

\subsection{Socio-economic Characteristics of Maize-Based Farmers in the Study Area}

\begin{tabular}{|c|c|c|}
\hline Variables & Frequency & Percentage \\
\hline \multicolumn{3}{|l|}{ Age } \\
\hline $30-39$ & 18 & 11.25 \\
\hline $40-49$ & 45 & 28.13 \\
\hline $50-59$ & 70 & 43.75 \\
\hline$>59$ & 27 & 16.87 \\
\hline \multicolumn{3}{|l|}{ Sex } \\
\hline Male & 121 & 75.63 \\
\hline Female & 39 & 24.37 \\
\hline \multicolumn{3}{|l|}{ Marital status } \\
\hline Single & 21 & 13.13 \\
\hline Married & 139 & 86.87 \\
\hline \multicolumn{3}{|l|}{ Education level } \\
\hline No formal Education & 18 & 11.25 \\
\hline Adult Education & 22 & 13.75 \\
\hline Primary education & 71 & 44.38 \\
\hline Secondary Education & 35 & 21.87 \\
\hline Tertiary education & 14 & 8.75 \\
\hline \multicolumn{3}{|c|}{ Years of farming experience } \\
\hline$<20$ & 56 & 35 \\
\hline $20-29$ & 74 & 46.25 \\
\hline $30-39$ & 19 & 11.88 \\
\hline $40-49$ & 11 & 6.87 \\
\hline \multicolumn{3}{|l|}{ Farm Size } \\
\hline$<2$ & 118 & 73.75 \\
\hline $2-4$ & 32 & 20 \\
\hline $4-5$ & 8 & 5 \\
\hline$>8$ & 2 & 1.25 \\
\hline \multicolumn{3}{|l|}{ Household size } \\
\hline$<2$ & 7 & 4.37 \\
\hline $2-4$ & 46 & 28.75 \\
\hline $5-8$ & 81 & 50.63 \\
\hline$>8$ & 26 & 16.25 \\
\hline
\end{tabular}

Results of the socio-economic characteristics of the respondents show that majority $(75.63$ percent) of the respondents in Ondo State were males while 86.87 percent of the respondents were married. The results further disclosed that most (59.82 percent) of the respondents were relatively old (more than 50 years) with the mean age of 54.76 years. Also, 50.63 percent of the respondents had between 5 and 8 members in their households. It was revealed that only 29.62 percent of the respondents had secondary education and above. The farmers were well experienced with 65 percent of them having more than 20 years of farming experience and 73.75 percent of them had less than 2 hectares of land as farm size.

Table 1. Socio-economic Characteristics of Farmers in the Study Area.

Source: Computed from field survey, 2016. 


\subsection{Effect of Technology on the Income of Maize-Based Farmers}

The cost-return structure of maize-based farmers in the study area is presented in table 2 . The variable cost constituted the largest percentage of the total production cost. The total revenue, gross margin and net farm income for the improved technology adopters are $\$ 750,450, \$ 573,130$ and
N52,1940respectively. On the other hand, the total revenue, gross margin and net farm income for the non-adopters of improved technology are $\$ 320,140, \$ 244,180$ and $\$ 227,830$ respectively. These figures suggest that improved technology adopters performed way better than non-adopters in terms of total revenue, gross margin and total cost.

Table 2. Cost-Return structure of maize based farmers.

\begin{tabular}{lllll}
\hline \multirow{2}{*}{ Items } & \multicolumn{2}{c}{ Adopters of improved technology } & \multicolumn{2}{c}{ Non- Adopters of improved technology } \\
\cline { 2 - 5 } & Mean ( $)$ & \% of total cost & Mean (\#) & \% of total cost \\
\hline A. Variable cost & & & & 31.69 \\
Cost of labour & 45,350 & 19.85 & 29,250 & 23.20 \\
Operating expenses & 33,115 & 14.49 & 21,420 & 19.19 \\
Cost of planting material & 40,530 & 17.74 & 17,710 & 8.21 \\
Cost of fertilizer & 8,500 & 3.72 & - & - \\
Cost of transportation & 15,525 & 6.79 & 7,580 & 82.29 \\
Cost of agrochemical & 34,300 & 15.01 & - & 14.29 \\
Total Variable Cost (TVC) & 177320 & 77.60 & 75,960 & 3.41 \\
Fixed Cost & & & & 17.71 \\
Cost on land leased & 32,540 & 14.24 & 13,200 & 100 \\
Depreciation & 18,650 & 8.16 & 3,150 & 16,350 \\
Total Fixed Cost & 51,190 & 22.40 & 92,310 & 320,140 \\
Total Cost & 228,510 & & 244,180 & 227,830 \\
Total Revenue & 750,450 & 100 & & \\
GM=TR-TVC & 573,130 & & & \\
Net farm income & 52,1940 & & & \\
\hline
\end{tabular}

Source: Computed from field survey, 2016.

\subsection{Determinants of Intensity of Adoption of Improved Technologies}

This section presents the results of Tobit model that showed how socio-economic characteristics of the farmers affected their intensity of adoption of improved technology. Adoption was measured in terms of the number of technologies used by a respondent. The likelihood estimates of the Tobit model indicated that chi-square $\left(\chi^{2}\right)$ statistic of 60.39 was highly significant $(\mathrm{P}<0.0001)$ suggesting that the model has a strong explanatory power. The pseudo coefficient of multiple determination $\left(\mathrm{R}^{2}\right)$ showed that 73.64 percent variation in the dependent variable was explained by the included independent variables. This implies that the model showed a good fit to the data. The results revealed that educational level, farming experience and household size were all statistically significant at $1 \%$ while age, marital status and extension service were statistically significant at 5\% each, implying that they were variables found to significantly influence the level of adoption of improved technologies in the study area. This result suggests that for every 1 unit increase in these variables, there is probability of increase in improved technologies adopted. The negative relationship that existed between the distance and the intensity of adoption indicates that the higher this variable was, the lesser the adoption, and vice-versa.
Table 3. Maximum Likelihood Estimates of Tobit Model.

\begin{tabular}{llll}
\hline Variables & Coefficient & Std. Error & P-value \\
\hline Age & $0.8426^{* *}$ & 0.3918 & 0.0421 \\
Sex & 0.7245 & 0.4893 & 0.2318 \\
Marital Status & $0.6533^{* *}$ & 0.2864 & 0.0354 \\
Educational Level & $0.4215^{* * *}$ & 0.1046 & 0.009 \\
Farming Experience & $0.9674^{* * *}$ & 0.1057 & 0.000 \\
Farm Size & $0.8745^{* * *}$ & 0.2563 & 0.001 \\
Distance & -0.4682 & 0.4528 & 0.7851 \\
Household Size & $0.8730^{* * *}$ & 0.1174 & 0.000 \\
Access to Loan & 0.4835 & 0.3985 & 0.1072 \\
Member of Techn. Group & 0.5409 & 0.4904 & 0.2851 \\
Extension Access & $0.7134^{* *}$ & 0.3021 & 0.0487 \\
Constant & $-0.538^{* * *}$ & 0.073 & 0.000 \\
Sigma & 0.133 & 0.009 & \\
LR Chi- square & 60.39 & & \\
Pseudo R & 73.64 & & \\
Log likelihood & 46.64 & & \\
\hline
\end{tabular}

*** and $* *$ represent $1 \%$ and $5 \%$ significance level respectively.

** represents $5 \%$ significance level

Source: Field Survey, 2016

\section{Conclusion}

It is concluded that despite the low level of education attained by the respondents they still embraced improved technology, meaning that the extension workers in the study area were majorly instrumental for the adoption of the improved technology for maize-based farmers. The figures of 
cost and return analysis disclosed that improved technology adopters performed better than non-adopters in terms of total revenue, gross margin and total cost. It can be inferred from the study that educational level, household size, farm size and farming experience greatly influenced the intensity of adoption of improved technology by maize-based farmers in the study area.

It is therefore recommended that policy option requires the traditional technology users to embrace the improved agricultural technologies in order to increase their earning per unit of land cultivated should be introduced, programs that would lead to increase in productivity and consequently increase household income should be put in place and there is need for improvement in the education of the traditional technology adopters as a panacea for adopting improved technology.

\section{References}

[1] Abdullahi, A. (2003). "Employment creation and opportunities in the agro-allied sub-sector: The case of cassava production.” CBN Bullion Publication, 27(4): 10.

[2] Encyclopaedia Britannica (2013). Ondo (State, Nigeria)Britannica Online Encyclopaedia. www.britannica.com/EBchecked/.../ondo.

[3] Directorate Agricultural Information Service in Cooperation with ARCGrain Crop Institute (2003).

[4] FAO (2007). Maize in Human Nutrition, Food and Agricultural Organization, Rome, Italy.
[5] FAOSTAT (2007). Food Security Statistics.

[6] Food and Agricultural Organization (2006): Rapid Growth of Selected Asian Countries.

[7] Kolawale O and Ojo S. O (2007), Economic efficiency of small scale food crop production in Nigeria. J. For Soc. Sci., 14(2): 123-130.

[8] Kudi, T. M., Bolaji, M., Akinola M. O. and Nasa'I D. H. (2011). " Analysis of adoption of improved maize varieties among farmers in Kwara State, Nigeria", International Journal of Peace and Development Studies Vol. 1(3), pp. 8-12, January 2011.

[9] National Agricultural Research Project (NARP). (1994). National Agricultural Research Strategy Plan for Nigeria (North-West Zone): Draft Report.

[10] National Bureau of Statistics/Central Bank of Nigeria (NBS/CBN) (2006), Socio-Economic survey on Nigeria, NBS, Abuja.

[11] Onuk E. G., Ogara I. M, Yahaya H and Nannim N (2010). "Economic Analysis of Maize Production in Mangu Local Government Area of Plateau State, Nigeria." PAT June, 2010; 6 (1): 1-11 ISSN: 0794-5213.

[12] Usman N. E (2006). “Agriculture: Vital to Nigerian Economic Development." Paper presented at the forum of Economic Stakeholders on "Growing the Nigeria Economy" 2006. This day News Paper, July 25, 2006.

[13] Wikipedia (2006): Corn Maize Wikipedia - The free encyclopedia. Www.wikipedia.org/maize access on the 16th December, 2006. 